\title{
Improved biomass and protein production in solid-state cultures of an Aspergillus sojae strain harboring the Vitreoscilla hemoglobin
}

\author{
Rodrigo Mora-Lugo $^{1}$ - Marvin Madrigal ${ }^{1,2}$ • Vikas Yelemane ${ }^{1}$. \\ Marcelo Fernandez-Lahore ${ }^{1}$
}

Received: 27 March 2015 /Revised: 8 July 2015 / Accepted: 15 July 2015 /Published online: 30 July 2015

(C) The Author(s) 2015. This article is published with open access at Springerlink.com

\begin{abstract}
The biotechnological value of Aspergillus sojae ATCC 20235 (A. sojae) for production of pectinases in solidstate fermentation (SSF) has been demonstrated recently. However, a common drawback of fungal solid-state cultures is the poor diffusion of oxygen into the fungi that limits its growth and biological productivity. The bacterial Vitreoscilla hemoglobin $(\mathrm{VHb})$ has favored the metabolism and productivities of various bacterial and yeast strains besides alleviating hypoxic conditions of its native host, but the use of $\mathrm{VHb}$ in filamentous fungi still remains poor explored. Based on the known effects of $\mathrm{VHb}$, this study assessed its applicability to improve $A$. sojae performance in SSF. The VHb gene $(\mathrm{vgb})$ under control of the constitutive Aspergillus nidulants gpdA promoter was introduced into the genome of A. sojae by Agrobacterium-mediated transformation. Successful fungal transformants were identified by fluorescence microscopy and polymerase chain reaction (PCR) analyses. In solid-state cultures, the content of protease, exopolygalacturonase (exo-PG), and exo-polymethylgalacturonase (exo-PMG) of the transformed fungus (A. sojae $\mathrm{vgb}+$ ) improved were 26,60 , and $44 \%$ higher, respectively, in comparison to its
\end{abstract}

Marcelo Fernandez-Lahore

m.fernandez-lahore@jacobs-university.de

Rodrigo Mora-Lugo

r.moralugo@jacobs-university.de

Marvin Madrigal

m.madrigalvillalobos@jacobs-university.de

Vikas Yelemane

v.yelemane@jacobs-university.de

1 Downstream Bioprocessing Lab, Jacobs University Bremen gGmbH, Bremen, Germany

2 Instituto Clodomiro Picado and Departamento de Bioquímica, Universidad de Costa Rica, San José, Costa Rica parental strain (A. sojae wt). Similarly, biomass content was also 1.3 times higher in the transformant strain. No significant difference was observed in endo-polygalacturonase (endo-PG) content between both fungal strains, suggesting dissimilar effects of $\mathrm{VHb}$ towards different enzymatic productions. Overall, our results show that biomass, protease, and exo-pectinase content of A. sojae in SSF can be improved by transformation with $\mathrm{VHb}$.

Keywords Agrobacterium tumefaciens-mediated transformation - Aspergillus sojae · Biomass production . Pectinases and protease $\cdot$ Solid-state fermentation $\cdot$ Vitreoscilla hemoglobin

\section{Introduction}

Protein production by means of solid-state fermentation (SSF) has gained a lot of interest in the last years because it has many advantages over the most widely used submerged fermentation $(\mathrm{SmF})$. For instance, the possibility to use low-cost substrates is a common benefit in solid-state cultures. Also, higher productivities, simpler equipment, and less space requirements are advantages associated to SSF (Aguilar et al. 2008; De la Cruz et al. 2014; Viniegra-Gonzalez et al. 2003). However, a major drawback in solid-state cultures with aerobic microorganisms is the lower diffusion of oxygen in the biomass which, in turn, limits the production of proteins (Stark et al. 2011; Wei and Chen 2008). To overcome oxygen limitations in fermentation processes, the co-expression of globins as a strain improvement strategy has proven to be useful in several aerobic hosts, including the filamentous fungi Aspergillus oryzae (Stark et al. 2011; te Biesebeke et al. 2006).

In various examples with prokaryotic and eukaryotic microorganisms, heterologous expression of the bacterial 
Vitreoscilla hemoglobin $(\mathrm{VHb})$ has improved cell growth and protein synthesis under oxygen-limiting conditions most likely by enhancing respiratory metabolism (Stark et al. 2011, 2015; Wei and Chen 2008). VHb is the best-characterized member of the bacterial hemoglobin proteins, and since the identification of its amino acid sequence (Wakabayashi et al. 1986), its application for strain improvement in various organisms has been widely explored. Mostly in bacterial and yeast bioprocesses, cell growth, bioremediation, and enhanced protein production have been improved within this so called " $v g b / \mathrm{NHb}$ technology" (Hofmann et al. 2009; Kahraman et al. 2011; Kahraman and Erenler 2012; Wu and Fu 2012; Zhu et al. 2011). However, the potential of $\mathrm{VHb}$ has not been investigated in detail in filamentous fungi, mainly due to the availability of fewer genetic molecular tools to engineer them in comparison to bacterial and yeast hosts (Fleissner and Dersch 2010; Mora-Lugo et al. 2014; Ward 2012).

The potential of the filamentous fungus Aspergillus sojae ATCC 20235 (A. sojae) for production of pectinases by fermentative processes has been demonstrated in the last years (Ustok et al. 2007; Tari et al. 2008; Demir et al. 2012; Heerd et al. 2014a). Pectinases or pectinolytic enzymes are a heterogeneous group of related enzymes that hydrolyze pectic substances or pectins and are valuable biocatalysts for food and industrial applications (Adapa et al. 2014). A. sojae has yielded higher amounts of pectinases in comparison with the well-known pectinase producer Aspergillus niger and other A. sojae strains (CBS 100928 and IMI 191303) in SSF (Heerd et al. 2012). Moreover, through classic mutagenesis screening strategies based on physical (ultraviolet irradiation) and chemical mutagens, pectinase titers of descending mutants of A. sojae have been improved in SmF and SSF (Heerd et al. 2014b). The potential of some of these highyield pectinase mutants has been further explored by measuring various pectinase activities including exo-/endopolygalacturonase (exo-PG/endo-PG), exopolymethylgalacturonase (exo-PMG), and pectin lyase using two different carbon sources in SSF (Mata-Gomez et al. 2014). Recently, an Agrobacterium tumefaciens-mediated transformation (ATMT) method was described for A. sojae, and heterologous expression of the enhanced green fluorescent protein (EGFP) was demonstrated successfully (MoraLugo et al. 2014). This study opens up new possibilities of protein expression studies in A. sojae and explore systematically strain improvement strategies for this fungus based on genetic molecular tools.

Based on the positive effects of $\mathrm{VHb}$ in previous microbial hosts, this study describes a genetic engineering approach to improve A. sojae for SSF. This fungus was genetically engineered with $\mathrm{VHb}$ through an adapted transformation method mediated by A. tumefaciens. Subsequently, different pectinases, protease, and biomass content were measured and compared between the transformed fungus $(A$. sojaevgb + ) and its parental strain (A. sojae wt) in solid-state cultures. The present study provides a new strain improvement strategy for A. sojae to further explore its potential as pectinase biofactory.

\section{Material and methods}

\section{Materials}

All chemicals were purchased from AppliChem GmbH (Darmstadt, Germany), except citrus pectin, galacturonic acid, polygalacturonic acid sodium salt, and D-(+)-glucosamine hydrochloride were obtained from Sigma-Aldrich Chemie $\mathrm{GmbH}$ (Steinheim, Germany). Microbial substrates like wheat bran, sugar beet pulp pellets, and molasses were obtained from local suppliers (Bremer Rolandmühle Erling $\mathrm{GmbH} \& \mathrm{Co}$. KG, Bremen, Germany; Nordzucker AG, Uelzen, Germany; Golden Sweet, Meckenheim, Germany). Restriction enzymes, T4 DNA polymerase, and T4 DNA ligase were purchased from New England Biolabs (Frankfurt am Main, Germany). Oligoprimers and DNA sequencing services were ordered from Eurofins (Ebersberg, Germany).

\section{Microorganisms and media}

A. sojae ATCC 20235 was grown at $28^{\circ} \mathrm{C}$ until conidiation (36 days) on molasses agar plates ( $45 \mathrm{~g} / 1$ molasses, $45 \mathrm{~g} / 1$ glycerol, $18 \mathrm{~g} / 1$ peptone, $5 \mathrm{~g} / 1 \mathrm{NaCl}, 0.5 \mathrm{~g} / \mathrm{l} \mathrm{KCl}, 15 \mathrm{mg} / 1 \mathrm{FeSO}_{4} \cdot 7 \mathrm{H}_{2} \mathrm{O}$, $60 \mathrm{mg} / 1 \mathrm{KH}_{2} \mathrm{PO}_{4}, 50 \mathrm{mg} / 1 \mathrm{MgSO}_{4}, 12 \mathrm{mg} / 1 \mathrm{CuSO}_{4} \cdot 5 \mathrm{H}_{2} \mathrm{O}$, $15 \mathrm{mg} / 1 \mathrm{MnSO}_{4} \cdot \mathrm{H}_{2} \mathrm{O}$, and $20 \mathrm{~g} / \mathrm{l}$ agar). Spores were harvested using $0.02 \%(w / v)$ Tween 80 and filtered through cotton to remove hyphae. The spore concentration was determined using a Neubauer chamber (Celeromics, Grenoble, France). Top 10 Escherichia coli cells (Invitrogen, CA, USA) were used as a host for all DNA manipulations. DNA plasmids were isolated from Luria-Bertani overnight cultures supplemented with $100 \mu \mathrm{g} / \mathrm{ml}$ streptomycin and $50 \mu \mathrm{g} / \mathrm{ml}$ kanamycin, using the "NucleoSpin Plasmid" commercial kit (Macherey-Nagel, Düren, Germany). Agrobacterium tumefaciens, strain LBA4404 (ElectroMAX ${ }^{\mathrm{TM}}$, Invitrogen, CA, USA), was used as donor of the transfer DNA (T-DNA) for fungal transformation of $A$. sojae.

\section{Construction of $v g b$-gene donor vector and fungal transformation}

The ATMT donor vector named pRM-vgb (GenBank Accession No KT225581) was designed for cloning and expression of the $v g b$ gene under control of the constitutive Aspergillus nidulants gpdA promoter (PgpdA) in A. sojae (Fig. 1). This vector was derived from the pRM-eGFP vector (Mora-Lugo et al. 2014) by subcloning a 1.7-kb synthetic cassette (ordered from Eurofins, Ebersberg, Germany) 


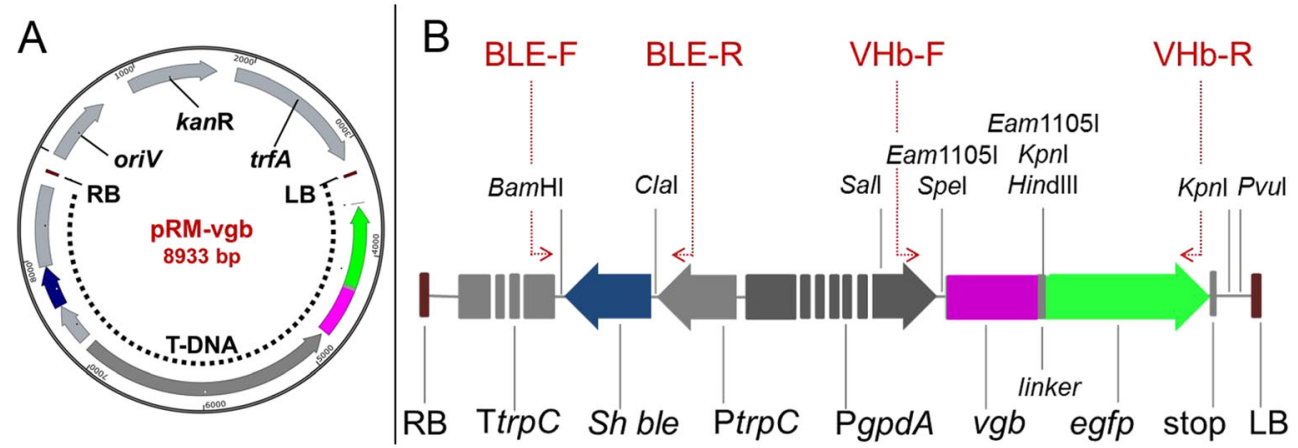

Fig. 1 a The vector pRM-vgb was used for ATMT of $A$. sojae and contains the kanamycin resistance gene ( $k a n \mathrm{R})$, trans-acting factor $\mathrm{A}$ gene $(\operatorname{trf} A)$, replication origin (oriV), and transfer DNA region (TDNA). b Enlargement of the T-DNA region that is delimited by the right and left border ( $R B$ and $L B$, respectively) and contains the Vitreoscilla hemoglobin gene $(v g b)$ and the reporter enhanced green fluorescent protein gene (egfp) under control of the constitutive

between $S a l$ and $P v u$ I restriction sites. This cassette contains $v g b$, which was codon usage optimized for Aspergillus species according to the CUTG database (GenBank) and fused to the $5^{\prime}$ end of the reporter egfp gene. Moreover, other additional restriction sites for forthcoming cloning strategies were added in this operon including two KpnI to enable deletion of egfp, if required, and two Eam1105I to allow TA cloning (by 3'T overhanging ends) for gene expression under control of the PgpdA (Alibu et al. 2005). The constructed pRM-vgb vector was electro-transformed into A. tumefaciens LBA4404, and recombinant bacteria were selected on LB agar plates containing $100 \mu \mathrm{g} / \mathrm{ml}$ streptomycin and $50 \mu \mathrm{g} / \mathrm{ml}$ kanamycin. Accuracy of the plasmid sequence was examined by restriction enzyme digestion and sequencing analysis. The recombinant $A$. tumefaciens strain containing the $\mathrm{pRM}$-vgb vector was used to transform $A$. sojae by the ATMT procedure as described by Mora-Lugo et al. (2014).

\section{Analysis of the fungal transformants}

Putative A. sojae transformants were assessed by PCR and fluorescence microscopy analysis to verify chromosomal integration and gene expression of the transformed or transferred DNA (T-DNA), respectively, as described by Mora-Lugo et al. (2014). For the PCR analysis, the genomic DNA from putative fungal transformants was isolated and used as DNA template. The specific primers sets BLE-F/BLE-R and VHb-F/VHb-R (Table 1) were used to target the ble and $v g b$ genes located in the T-DNA region, respectively. Amplification included an initial denaturation at $94{ }^{\circ} \mathrm{C}$ for $5 \mathrm{~min}$, followed by 30 cycles of denaturation at $94{ }^{\circ} \mathrm{C}$ for $15 \mathrm{~s}$, annealing for $40 \mathrm{~s}$ (at $55^{\circ} \mathrm{C}$ for ble and at $59^{\circ} \mathrm{C}$ for $v g b$ ), and elongation at $68^{\circ} \mathrm{C}$ for $60 \mathrm{~s}$, and a final elongation step at $68{ }^{\circ} \mathrm{C}$ for $5 \mathrm{~min}$. Genomic DNA from the parental $A$. sojae wt strain and purified pRM-vgb plasmid were used as a negative and positive control, respectively. For
Aspergillus nidulants gpdA promoter $(\operatorname{Pg} p d A)$, the phleomycin resistance gene from Stretoalloteichus hindustanus (Sh ble) under control of the A. nidulants trpC promoter (PtrpC) and trpC terminator $(\operatorname{TtrpC})$. The red arrows indicate the target sites for the oligonucleotide primers BLE-F/R, VHb-F/R. Target sites for restriction enzymes are also shown

the fluorescence microscopy analysis, the expression of EGFP reporter gene in $A$. sojae transformants was visualized using an Axioplan 2 imaging (Zeiss) microscope equipped with a filter set matching the excitation and emission spectra for the EGFP (Ex/Em=488/509). Images were acquired with the AxioVision ( $V .4 .8)$ software, setting an exposure time of $900 \mathrm{~ms}$ to subtract the background autofluorescence signal of the $A$. sojae wt.

\section{Solid-state fermentation at flask scale}

SSF experiments were carried out independently, in triplicates, and for 10 days with an untransformed (A. sojae wt) and a selected transformed fungal strain $(A$. sojae $\mathrm{vgb}+)$ according to the method provided by Heerd et al. (2014b) with slight modifications. Erlenmeyer flasks $(300 \mathrm{ml})$ containing $10 \mathrm{~g}$ of wheat bran and ground sugar beet pulp in the ratio $70: 30$ and wetted at $160 \%$ with $16 \mathrm{ml}$ of $0.2 \mathrm{M} \mathrm{HCl}$ solution were sterilized at $121{ }^{\circ} \mathrm{C}$ for $20 \mathrm{~min}$. Each flask was inoculated with a total number of $2 \times 10^{7}$ fungal spores and incubated at $30^{\circ} \mathrm{C}$. A non-inoculated flask was used as a control sample blank. A replicate for each fungal strain consisted of ten individual flasks, and one of each was used once every day for sampling. Fermentation samples were collected by adding $80 \mathrm{ml}$ distilled water per flask, homogenized partially with a spatula, and mixed in an incubator shaker (Innova 4230, New Brunswick Scientific) at $250 \mathrm{rpm}$ and $25{ }^{\circ} \mathrm{C}$ for $1 \mathrm{~h}$. The supernatants were clarified by centrifugation at $3200 \times \mathrm{g}$ and $4{ }^{\circ} \mathrm{C}$ for $20 \mathrm{~min}$ and filtration through Whatman \#1 (11 $\mu \mathrm{m}$ pore size) and set aside for protein content analyses. The precipitated pellets (wet fermented substrate) were lyophilized for 2 days with freeze dryer (Alpha 12/LD plus, Christ, Osterode am Harz, Germany), ground to a fine powder with mortar and pestle, and set aside for glucosamine content (fungal biomass analyses). 
Table 1 Sequences of the primers used for PCR amplification

\begin{tabular}{lll}
\hline Primer name & Primer sequence & Reference \\
\hline BLE-F & 5'-CGTTTTATTCTTGTTGACATGGAGC-3' & Mora-Lugo et al. (2014) \\
BLE-R & 5'-TTGGGCTTGGCTGGAGCTAGTGGAG-3' & \\
VHb-F & 5'-CAGTTCGAGCTTTCCCACTTCATCG-3' & This study \\
VHb-R & 5'-TGTACAGCTCGTCCATGCCGAGAGT-3' & \\
\hline
\end{tabular}

\section{Protein production}

Different protein contents (exo-PG, exo PMG, endo-PG, and protease) were measured from the clarified extracts and expressed as enzymatic activity unit per gram of substrate $(\mathrm{U} / \mathrm{g})$. The data obtained were represented as mean $\pm \mathrm{SD}$.

\section{Exo-polygalacturonase and exo-polymethylgalacturonase}

Exo-PG and exo-PMG activities were measured according to previously described protocols (Blandino et al. 2002; Heerd et al. 2012; Silva et al. 2005) with slight modifications. The assays were performed in a microplate by mixing $10 \mu \mathrm{l}$ of enzymatic sample and $90 \mu \mathrm{l}$ of $5 \mu \mathrm{g} / \mu \mathrm{l}$ of substrate (polygalacturonic acid (PGA) for exo-PG activity and citrus pectin for exo-PMG activity) in a $100 \mathrm{mM}$ citrate- $\mathrm{Na}$ biphosphate buffer $\mathrm{pH}$ 5.0. The reduced galacturonic acid (GA) released by the reaction after $30 \mathrm{~min}$ of incubation at $30{ }^{\circ} \mathrm{C}$ for exo-PG activity and $10 \mathrm{~min}$ of incubation at $45^{\circ} \mathrm{C}$ for exo-PMG activity was quantified by the DNS method at $575 \mathrm{~nm}$ (Miller 1959) and compared to a GA standard curve. One unit of exo-enzyme activity was defined as the amount of enzyme that catalyzes the release of $1 \mu \mathrm{mol}$ of GA per minute at the standard assay conditions mentioned above.

\section{Endo-polygalacturonase}

Endo-PG activity was measured according to an adapted method from (Ortiz et al. 2014). The assay was performed in a microplate by mixing $8 \mu \mathrm{l}$ of enzymatic sample and $8 \mu \mathrm{l}$ of $5 \mu \mathrm{g} / \mu \mathrm{l}$ PGA substrate in a $100 \mathrm{mM}$ citrate-Na biphosphate buffer $\mathrm{pH}$ 5.0. The hydrolyzed PGA unable to precipitate with ruthenium red dye (RR) after 20 min of reaction at $40^{\circ} \mathrm{C}$ was measured at $535 \mathrm{~nm}$ and compared to a PGA standard curve (from 0 to $36 \mu \mathrm{g}$ ). One unit of enzyme activity was defined as the amount of enzyme required to hydrolyze $1 \mu \mathrm{g}$ of PGA in smaller fragments unable to precipitate with RR per minute at the standard assay conditions mentioned above.

\section{Protease}

Protease activity was measured according to the commercial Pierce protease assay kit (Thermo Scientific, Illinois, USA). The assay was performed in a microplate by mixing $50 \mu$ of enzymatic sample and $100 \mu \mathrm{l}$ of $2 \mu \mathrm{g} / \mu \mathrm{l}$ succinylated casein (substrate) in a $50 \mathrm{mM}$ borate buffer $\mathrm{pH} 8.5$. The released tyrosine (product) by the reaction after $20 \mathrm{~min}$ of incubation at $37^{\circ} \mathrm{C}$ was measured at $450 \mathrm{~nm}$ and compared to a TPCKtrypsin standard curve. One unit of protease activity was defined as the amount of enzyme that converts as much substrate as $1 \mu \mathrm{g}$ of TPCK-trypsin (standard protease) per minute at the standard assay conditions mentioned above.

\section{Total soluble protein}

Total soluble protein was measured in SSF-supernatant samples according to the modified Bradford method (Bradford 1976) from the commercial Coomassie Plus ${ }^{\mathrm{TM}}$ Protein Assay Kit (Thermo Scientific, Illinois, USA). The assay was performed using the standard microplate protocol and bovine serum albumin (included in the kit) as a standard. Absorbance values were measured at $595 \mathrm{~nm}$.

\section{Biomass production}

The glucosamine (GlcN) released by acid hydrolysis of chitin present in the cell wall of the filamentous fungi was measured as an indirect method to estimate biomass content in the fermented samples. GlcN content in samples of $0.1 \mathrm{~g}$ of dried fermented substrate (dfs) was assessed according to Zamani et al. (2008) with slight modifications and compared to a standard curve of $\mathrm{D}-(+)$-glucosamine hydrochloride. Fungal biomass was expressed in terms of milligram of GlcN $\left(\mathrm{mg}_{\mathrm{GlcN}}\right)$ per gram of dfs (from here on referred just as $\mathrm{mg} / \mathrm{g}$ ). The data obtained were represented as mean \pm SD.

\section{Results}

\section{Cloning of $v g b$ gene in $A$. sojae}

The $\mathrm{VHb}$ gene $(v g b)$ was transformed into A. sojae ATCC 20235 following the protocol described by Mora-Lugo et al. (2014). A. tumefaciens LBA4404 containing the vector pRM$\mathrm{vgb}$ (Fig. 1a) was utilized for chromosomal integration of the T-DNA element containing $v g b$ as well as the ble gene for phleomycin resistance (Fig. 1b). A. sojae transformants were selected from minimal medium agar plates containing 
$50 \mu \mathrm{g} / \mathrm{ml}$ phleomycin. After 4 days of incubation, eight fungal colonies per $10^{5}$ conidia were obtained from the selection plates. These putative transformants were subcultured individually on PDA plates supplemented with $100 \mu \mathrm{g} / \mathrm{ml}$ phleomycin for four generations to evaluate the stability of the T-DNA that confers antibiotic resistance. Three out of eight transformants survived after the antibiotic treatment and were used for further analysis.

\section{Verification of transformation using PCR}

The three obtained phleomycin-resistant transformants were examined by PCR analysis to confirm successful chromosomal integration of the T-DNA cassette. Genomic DNA from these strains and their parental strain (A. sojae wt) as negative control were used to target the ble and $v g b$ genes by PCR with the specific primers sets BLE-F/R and VHb-F/R (Table 1), respectively. PCR products of expected sizes of $905 \mathrm{bp}$ for ble and $1281 \mathrm{bp}$ for $v g b$ were obtained from the transformants while in the wild-type sample, these DNA regions were absent (Fig. 2). Bidirectional sequencing of the PCR products with the primers used for PCR confirmed the identity of ble and $v g b$ and thus successful integration of these genes into the genome of the $A$. sojae transformants.

\section{Verification of egfp expression using fluorescence microscopy}

Additionally to the presence of the egfp reporter gene by PCR analysis, expression of the gene in the fungal transformants was verified by fluorescence microscopy analysis. Fluorescence

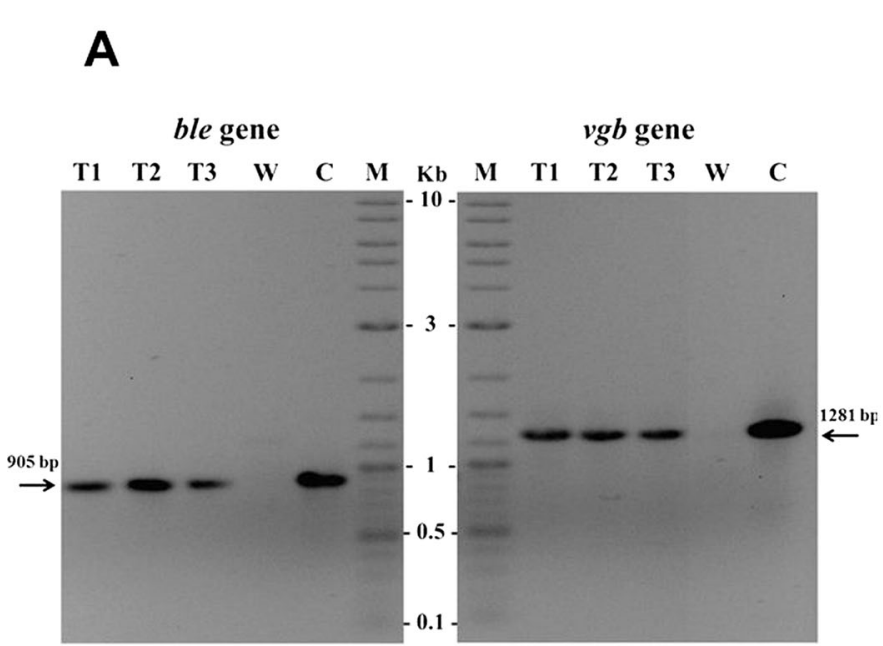

Fig. 2 a Verification of putative $A$. sojae transformants by PCR analysis. The amplified PCR products at the expected size (highlighted with arrows) confirm the presence of the ble gene and the $v g b$ gene in the genomic DNA samples of the fungal transformants. Genomic DNA of signals were observed in the fungal transformants containing $v g b$ and $e g f p$ in the same operon. In contrast, we observed no fluorescence signal in the parental A. sojae wt (Fig. 2). Fluorescence microscopy analysis facilitated further control and discrimination between transformed and untransformed fungus as there was no noticeable morphological difference between these fungal colonies.

After PCR and fluorescence microscopy analysis, the three positive fungal transformants were screened on agar plates supplemented with PGA to determine variation of pectinolytic activity between themas described by Martos et al. (2013). As there was neither difference in the zones of pectin hydrolysis on the agar plates nor phenotypical changes observed between the fungi, one of the positive transformants was randomly selected $(A$. sojae $\mathrm{vgb}+$ ) to carry out all the subsequent SSF experiments.

\section{SSF with the transformed and untransformed fungus}

The growth of the transformant $A$. sojae $\mathrm{vgb}+$ and parental A. sojae wt strain in the solid-state cultures was visually examined. Both fungal strains showed a similar grow pattern during each of the entire fermentation period of 10 days (Fig. 3). The first mold growth was observable 2 days after inoculation, and mycelia were patchily distributed on the substrate. Abundant mycelial growth was observed after 4 days of fermentation with total colonization of the solid substrate by day 6 . The first conidia production was observed after 6 to 7 days of fermentation reaching its maximum content by the end of the fermentation at day 10 , where conidia are indicated by the green color (Fig. 3).

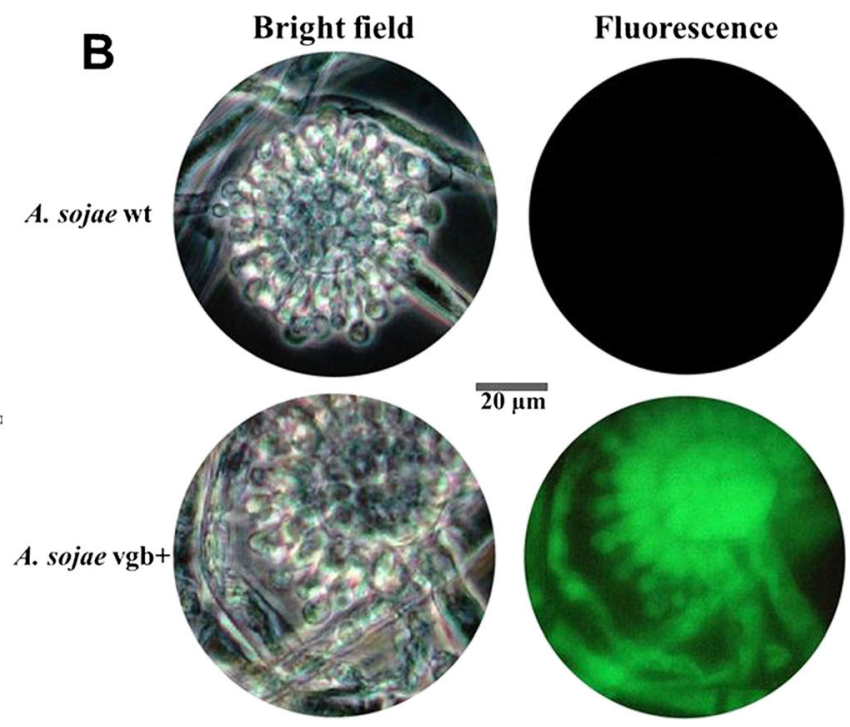

A. sojae wt was used as negative $(W)$ and purified pRM-vgb vector as positive control $(C)$; molecular size marker $(M)$. b Verification of $e g f p$ expression in the selected $A$. sojae vgb+transformant by fluorescence microscopy analysis. A. sojae wt was used as negative control 
Fig. 3 Typical growth of $A$. sojae wt and $A$. sojae $\mathrm{vgb}+$ on solid substrate during the 10-day fermentation period (only selected days are shown). The column on the left shows a representative flask of the inoculation day (0), and the column on the right shows the non-inoculated control media after 10 days of incubation under the same conditions $(C)$

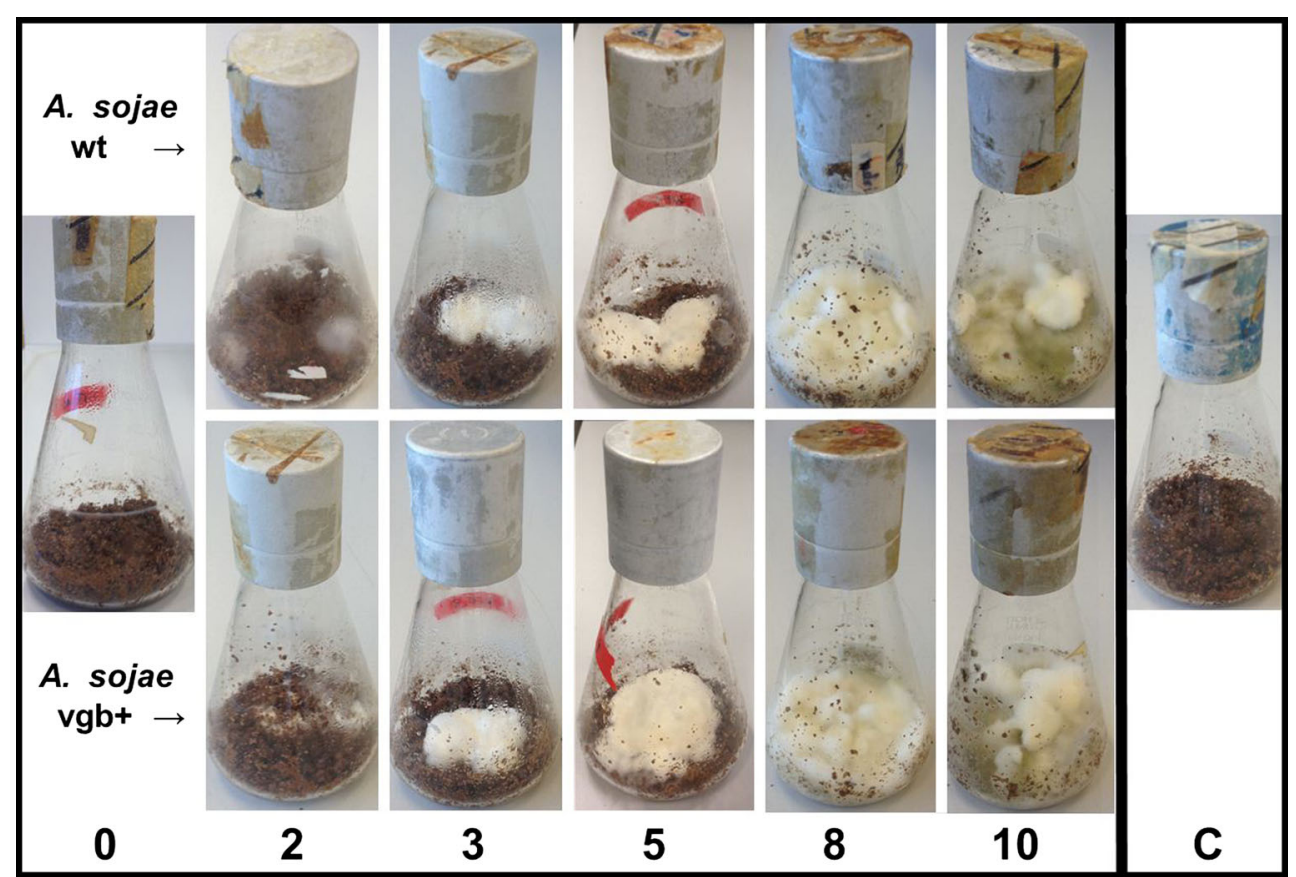

\section{Production of extracellular proteins}

To evaluate whether $\mathrm{VHb}$ had a positive effect on the production of extracellular proteins of $A$. sojae in SSF, fermented samples of the transformant $A$. sojae $\mathrm{vgb}+$ and parental $A$. sojae wt strain were harvested daily and assessed for various enzymatic activities. A clear difference in protein production was observed between both fungal strains (Fig. 4). Regarding to pectinase production, the maximum exo-PG and exo-PMG titers of 562.1 and $75.4 \mathrm{U} / \mathrm{g}$ after 7 days of fermentation with $A$. sojae $\mathrm{vgb}+$ were nearly 1.60 -fold and 1.45 -fold higher, respectively, in comparison to the wildtype strain (Fig. 4a-b). However, no relative increase of endo-PG content was measured in the recombinant fungus, compared to the wild-type strain. In this case, the maximum endo-PG titer of $132.1 \mathrm{U} / \mathrm{g}$ was observed for the wild-type strain after 6 days of fermentation (Fig. 4c). Regarding protease production, the maximum quantity of $39.2 \mathrm{U} / \mathrm{g}$ was nearly 1.25 -fold higher in the transformed fungus compared to the parental strain after 6 days of fermentation (Fig. 4d). Overall, the maximum enzymatic titers for both fungal strains were between the sixth and seventh day of fermentation. The $\mathrm{pH}$ of all enzymatic extracts increased overtime ranging from $\mathrm{pH} 3.9 \pm 0.3$ at the start to $\mathrm{pH} 5.8 \pm 0.5$ at the end of the fermentation, in both the transformant and wild-type strains.

\section{Biomass production}

The production of biomass of $A$. sojae wt and $A$. sojae $\mathrm{vgb}+$ on the solid-state cultures was indirectly evaluated by measuring the glucosamine content of the cell wall of the fungi. In general, biomass titers were higher in the transformed fungus in comparison to the wild-type cultures, with significantly improved levels between the seventh and tenth day of fermentation (Fig. 5). The maximum glucosamine content of $6.9 \mathrm{mg} /$ $\mathrm{g}$ measured in the recombinant fungus after 8 days of fermentation was 1.33 -fold higher compared to the maximum content of the parental strain after 6 days of fermentation. Such improvement of biomass content in $A$. sojae $\mathrm{vgb}+$ was similar in order of magnitude to its improved levels of extracellular protein such as protease and exo-pectinases.

Figure 6 summarizes the various enzymatic and biomass maximum yields for both fungal strains, where standard errors never exceeded $10 \%$.

\section{Discussion}

A. sojae ATCC 20235 has demonstrated recently its potential for pectinase production in fermentation systems and particularly in SSF (Demir et al. 2012; Gogus et al. 2006; Heerd et al. 2014a, 2014b, 2012; Mata-Gomez et al. 2014; Tari et al. 2008, 2007; Ustok et al. 2007). However, it is generally assumed that there is a limitation in the oxygen supply to the cells that are in close contact with the substrate in solid-state cultures with filamentous fungi (Oostra et al. 2001; Rahardjo et al. 2005). Previous studies have demonstrated beneficial effects of $\mathrm{VHb}$ to alleviate hypoxic conditions in several bacteria and yeast hosts (various summarized in Wei and Chen 2008; Stark et al. 2011, and Stark et al. 2015). Thus, this study was aimed to alleviate hypoxic conditions for $A$. sojae in SSF by genetically engineering this fungus with the $\mathrm{VHb}$ in order to 

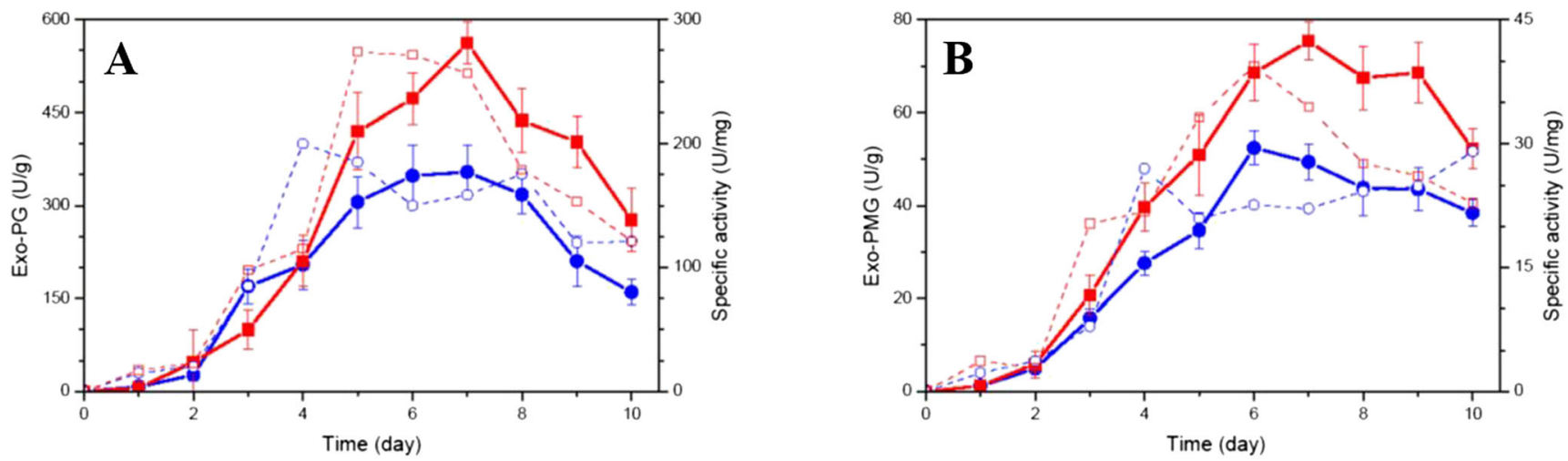

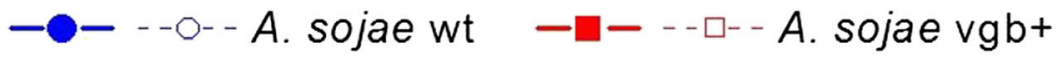

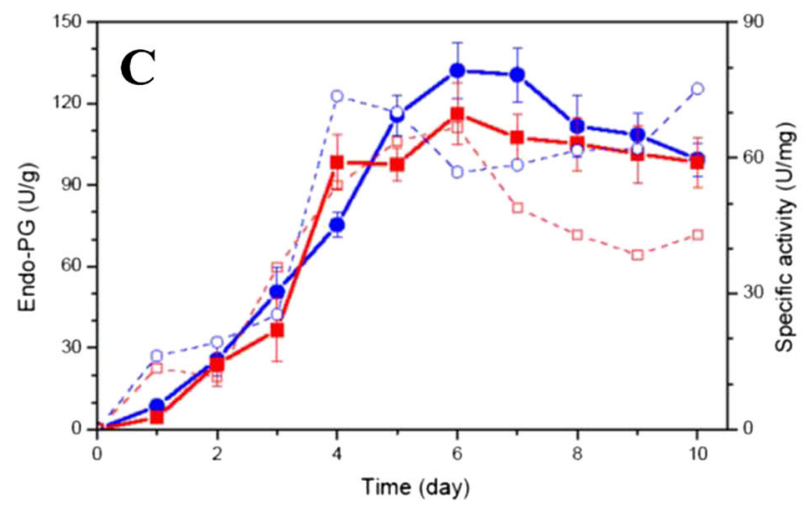

Fig. 4 Protein production of $A$. sojae wt and $A$. sojae vgb+in SSF. ExoPG (a), exo-PMG (b), endo-PG (c), and protease (d) content were determined from enzymatic extracts collected every $24 \mathrm{~h}$ during the $10-$

improve its cell growth and protein production levels. The effect of this hemoglobin in $A$. sojae was not explored until now, and this so called $v g b / \mathrm{NHb}$ technology has rarely been used for SSF applications.

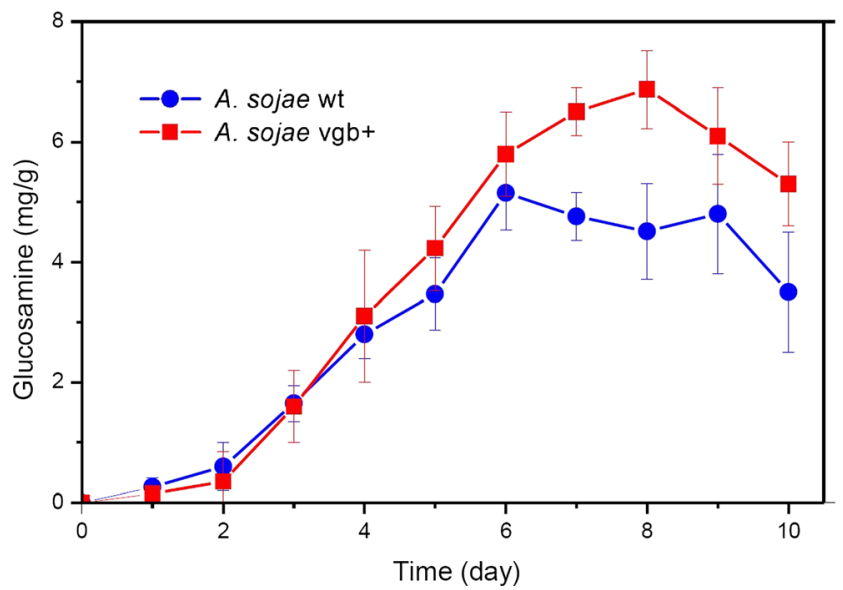

Fig. 5 Biomass content of $A$. sojae wt and $A$. sojae $\mathrm{vgb}+$ in SSF. The values plotted are expressed as milligram of glucosamine $\left(\mathrm{mg}_{\mathrm{GlcN}}\right)$ per gram of dried fermented substrate (dfs), which were collected every $24 \mathrm{~h}$ during the 10-day incubation time. Each data point represents the average \pm SD from fermentations carried out in triplicates

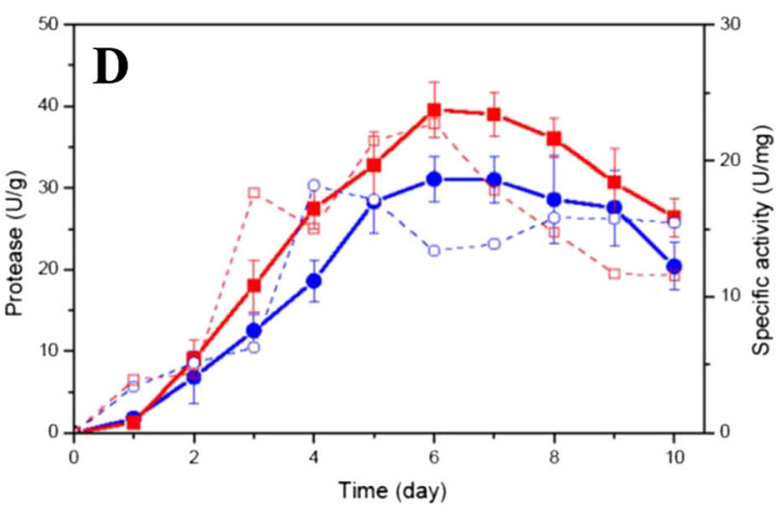

day incubation period. Solid lines indicate the enzymatic yield, and dashed lines indicate specific activity. Each data point represents the average \pm SD from fermentations carried out in triplicates

The $\mathrm{VHb}$ gene under control of the constitutive $A$. nidulants gpdA promoter (PgpdA) was integrated into the genome of $A$. sojae by an adapted method mediated by A. tumefaciens (ATMT). This transformation method was selected as its applicability for this fungus was previously

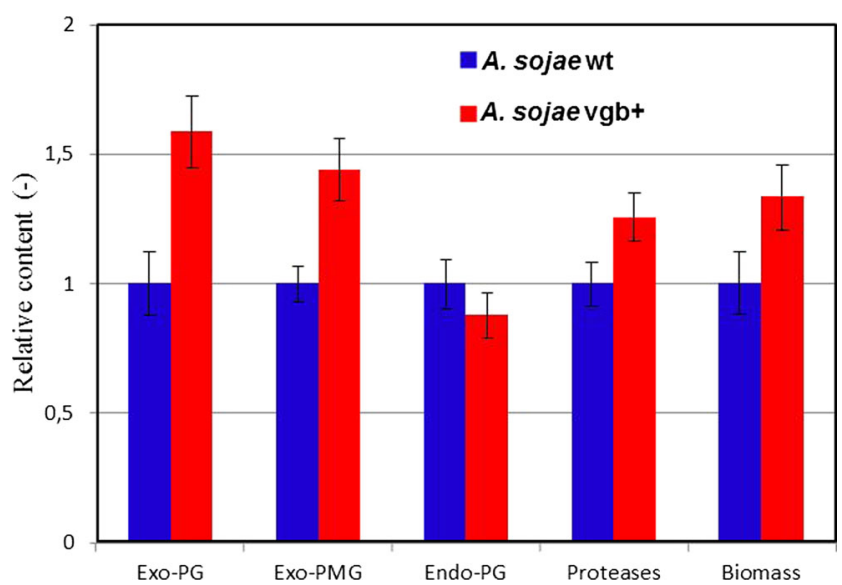

Fig. 6 Relative yields of $A$. sojae wt and $A$. sojae $\mathrm{vgb}+$ in SSF. The maximum yields of the parental $A$. sojae wt strain were adjusted to 1.0 and compared with the normalized maximum titers of the transformed A. sojae $\mathrm{vgb}+$ strain 
demonstrated (Mora-Lugo et al. 2014). Likewise, chromosomal integration of the transformed T-DNA cassette and expression of the reporter EGFP was successfully confirmed, indicating the presence of the protein product of $v g b$ in the fungal transformants (Fig. 2). However, about ten times fewer putative transformants (eight fungal colonies per $10^{5}$ conidia) were obtained in comparison to the previous study. A 482-bp larger T-DNA fragment was cloned in this study, which may have resulted in a lower number of transformants. Similarly, it is known from other studies on fungi, bacteria, and plant cells that increasing DNA fragment size can result in lower transformation efficiencies (Fleming et al. 1995; Gouka et al. 1999; Kung et al. 2013). Nevertheless, the genetic stability of the TDNA cassette in the transformants was comparable to the mitotic stability rate of $40 \%$ previously reported (MoraLugo et al. 2014). Our results demonstrate thus that even though transformation efficiency was relatively low, mitotically stable transformants can be obtained by the adapted ATMT method and indicate the applicability of this approach to explore the $v g b / \mathrm{VHb}$ technology on $A$. sojae for fermentation experiments.

Our results also show that $A$. sojae harboring the $v g b$ gene (A. sojae $\mathrm{vgb}+$ ) yields higher amounts of biomass, protease, and exo-pectinases in comparison to its parental strain $A$. sojae $\mathrm{wt}$ in SSF (Figs. 4-6). The results are in good agreement with recent reports of fungi, where increased levels of biomass and metabolite yields were associated with heterologous expression of $\mathrm{VHb}$. For instance, improved biomass, spore, and protease production by the filamentous fungus Paecilomyces lilacinus and increased yields of total flavones and exopolysaccharides by Phellinus igniarius were obtained in $\mathrm{SmF}$ when engineering these fungi with $\mathrm{VHb}$ (Zhang et al. 2014; Zhu et al. 2011). Also, expression of the VHb in Aspergillus niger resulted in advantageous effects on the physiology of this fungus under oxygen-limiting conditions (Hofmann et al. 2009). Similarly, the increased biomass and extracellular-enzymatic content of $A$. sojae $\mathrm{vgb}+$ in our fermentation showed that overall $\mathrm{VHb}$ improved the strain's adaptability to the fermentation conditions. The maximum productivities of the transformed and untransformed strain between the fourth and ninth day of fermentation were in good agreement with recent SSF with the parental fungus (Heerd et al. 2014b, 2012; Mata-Gomez et al. 2014) and demonstrated thus an unaltered time shifting on enzyme productivity by $\mathrm{VHb}$. The highest mycelial density observed during this period of maximum productivities indicates also the importance of this morphological stage for the production of proteins by A. sojae (Fig. 3).

Contrary to the increase of biomass, protease, and exopectinase content in SSF, endo-PG production did not improve with $A$. sojae $\mathrm{vgb}+$ but was rather slightly lower in comparison to its parental $A$. sojae wt strain, at least during the stationary phase of fermentation between the fourth and eighth day (Fig. 4c). Similarly, it was shown that heterologous expression of $\mathrm{VHb}$ in $E$. coli appears to affect expression of several of its native genes in a different manner, either positively or negatively (Roos et al. 2004). In agreement with the previous study, the transformed $\mathrm{VHb}$ in $A$. sojae $\mathrm{vgb}+\operatorname{did}$ not affect the production of different extracellular protein equally but rather favored certain enzymatic activities. The higher exo- to endo-pectinase activities suggest that under the SSF conditions, exo-pectinase activities are more essential for A. sojae $\mathrm{vgb}+$, possibly to increase its biomass content. The more energy invested in exo-PG and biomass content may be connected to a trade-off concerning endo-PG production. Extending the investigation to other enzymatic activities besides hydrolases on A. sojae vgb + may uncover novel potential applications of this fungus.

Even though $\mathrm{VHb}$ has been extensively assessed, to date there is not a comprehensive understanding of how its expression affects biological production. In recent applications of $\mathrm{VHb}$ on fungi and yeast, where beneficial effects on growth and enzyme levels have been demonstrated, it has been pointed out that the mechanism of $\mathrm{VHb}$ can be rather complex (Shen et al. 2012; Wang et al. 2014; Wu and Fu 2012; Zhang et al. 2014). The common conception is that under oxygen-limiting conditions, $\mathrm{VHb}$ is induced in order to bind the remaining oxygen and deliver it to the terminal respiratory oxidase(s) to maintain aerobic respiration at a high level under these conditions (Stark et al. 2011; Webster 1987). VHb may also take part in various steps of the respiratory chain as terminal electron acceptor by improving ATP production or showing peroxidase activity; hence, the beneficial effects of $\mathrm{VHb}$ expression are presumably the result of one or more of its activities (Isarankura-Na-Ayudhya et al. 2010; Liao et al. 2014; Stark et al. 2015). Knowing that $A$. sojae has an aerobic metabolism, it may be implied that $\mathrm{VHb}$ favored the flux of oxygen in the transformant $A$. sojae $\mathrm{vgb}+$ during the SSF conditions, making this fungal strain able to consume more solid substrate and, in turn, increase biomass and several of its enzymatic contents. te Biesebeke et al. (2006) described that improvements on cell growth and enzymatic yields in an A. oryzae strain expressing hemoglobin domains similar to $\mathrm{VHb}$ may be due to an improved hyphae capacity to penetrate solid substrates. However, preliminary microscopic observations (data not shown) evidenced no remarkable difference on hyphal penetration depth between $A$. sojae $\mathrm{vgb}+$ and $A$. sojae wt on fermented substrate. This indicates that the major contribution of $\mathrm{VHb}$ on the transformed fungus may lie in its metabolism rather than in its phenotype. Even though the exact $\mathrm{VHb}$ mechanism on $A$. sojae still needs to be shown, the present study demonstrated clearly that $\mathrm{VHb}$ had a positive effect on $A$. sojae metabolism in solid-state cultures. Future SSF studies with the transformant $A$. sojae $\mathrm{vgb}+$ will show whether $\mathrm{VHb}$ will also have the same effect on the strain's metabolism at a reactor scale. 
In summary, this study genetically improved $A$. sojae ATCC 20235 for SSF application using the adapted ATMT method to integrate $v g b$ under control of the constitutive PgpdA into the genome of this fungus. The transformed fungus $A$. sojae $\mathrm{vgb}+$ showed improved biomass, protease, and exo-pectinase production, while its endo-PG content appeared slightly diminished in comparison to its parental strain in solid-state cultures. The fungal transformants generated within this study are suitable candidates to be evaluated in SFF scale-up studies in bioreactors. Based on our results, this genetic engineering strategy may also enable further optimization of $A$. sojae as a microbial biomanufacturing platform for pectinolytic enzymes, e.g., by iterative cycles of mutagenesis.

Acknowledgments This work was funded by the people Programme of the European Union's Seventh Framework Programme PGSYS EXCHANGE/FP7-PEOPLE-2010-IRSES, and a CONACYT-DAAD fellowship (awarded to RML). The authors thank Judith Zimmermann for reviewing this article and useful suggestions.

Conflict of interest The authors declare that they have no conflict of interest.

Open Access This article is distributed under the terms of the Creative Commons Attribution 4.0 International License (http:// creativecommons.org/licenses/by/4.0/), which permits unrestricted use, distribution, and reproduction in any medium, provided you give appropriate credit to the original author(s) and the source, provide a link to the Creative Commons license, and indicate if changes were made.

\section{References}

Adapa V, Ramya LN, Pulicherla KK, Rao KRSS (2014) Cold active pectinases: advancing the food industry to the next generation. Appl Biochem Biotech 172:2324-2337

Aguilar CN, Guti G, Prado-Barragán LA, Rodríguez-Herrera R, Martínez-Hernandez JL, Contreras-Esquivel JC (2008) Perspectives of solid state fermentation for production of food enzymes. Am J Biochem Biotechnol 4:354-366

Alibu VP, Storm L, Haile S, Clayton C, Horn D (2005) A doubly inducible system for RNA interference and rapid RNAi plasmid construction in Trypanosoma brucei. Mol Biochem Parasit 139:75-82. doi: 10.1016/j.molbiopara.2004.10.002

Blandino A, Iqbalsyah T, Pandiella SS, Cantero D, Webb C (2002) Polygalacturonase production by Aspergillus awamori on wheat in solid-state fermentation. Appl Microbiol Biot 58:164-169. doi:10. 1007/s00253-001-0893-4

Bradford MM (1976) A rapid and sensitive method for the quantitation of microgram quantities of protein utilizing the principle of protein-dye binding. Anal Biochem 72:248-254

De la Cruz QR, Roussos S, Hernandez D, Rodriguez R, Castillo F, Aguilar CN (2014) Challenges and opportunities of the bio-pesticides production by solid-state fermentation: filamentous fungi as a model. Crit Rev Biotechnol. doi:10.3109/07388551.2013.857292

Demir H, Gogus N, Tari C, Heerd D, Lahore MF (2012) Optimization of the process parameters for the utilization of orange peel to produce polygalacturonase by solid-state fermentation from an Aspergillus sojae mutant strain. Turk J Biol 36:394 404. doi:10.3906/Biy-1104-23
Fleissner A, Dersch P (2010) Expression and export: recombinant protein production systems for Aspergillus. Appl Microbiol Biot 87:12551270. doi:10.1007/s00253-010-2672-6

Fleming GH, Kramer CM, Le T, Shillito RD (1995) Effect of DNA Fragment size on transformation frequencies in tobacco (Nicotiana tabacum) and maize (Zea mays). Plant Sci 110:187-192. doi:10. 1016/0168-9452(95)04196-2

Gogus N, Tari C, Oncu S, Unluturk S, Tokatli F (2006) Relationship between morphology, rheology and polygalacturonase production by Aspergillus sojae ATCC 20235 in submerged cultures. Biochem Eng J 32:171-178. doi:10.1016/j.bej.2006.09.023

Gouka RJ, Gerk C, Hooykaas PJ, Bundock P, Musters W, Verrips CT, de Groot MJ (1999) Transformation of Aspergillus awamori by Agrobacterium tumefaciens-mediated homologous recombination. Nat Biotechnol 17:598-601. doi:10.1038/9915

Heerd D, Diercks-Horn S, Fernandez-Lahore M (2014a) Efficient polygalacturonase production from agricultural and agro-industrial residues by solid-state culture of Aspergillus sojae under optimized conditions. Springer Plus 3:742

Heerd D, Tari C, Fernandez-Lahore M (2014b) Microbial strain improvement for enhanced polygalacturonase production by Aspergillus sojae. Appl Microbiol Biotechnol 98:7471-7481. doi:10.1007/ s00253-014-5657-z

Heerd D, Yegin S, Tari C, Fernandez-Lahore M (2012) Pectinase enzyme-complex production by Aspergillus spp. in solid-state fermentation: a comparative study. Food Bioprod Process 90:102-110. doi:10.1016/j.fbp.2011.08.003

Hofmann G, Diano A, Nielsen J (2009) Recombinant bacterial hemoglobin alters metabolism of Aspergillus niger. Metab Eng 11:8-12. doi: 10.1016/j.ymben.2008.07.002

Isarankura-Na-Ayudhya $\mathrm{C}$, Tansila $\mathrm{N}$, Worachartcheewan $\mathrm{A}$, Bulow L, Prachayasittikul V (2010) Biochemical and cellular investigation of Vitreoscilla hemoglobin $(\mathrm{VHb})$ variants possessing efficient peroxidase activity. J Microbiol Biotechnol 20:532-541. doi:10.4014/ jmb.0908.08038

Kahraman H, Aytan E, Kurt AG (2011) Production of methionine gamma-lyase in recombinant Citrobacter freundii bearing the hemoglobin gene. BMB Rep 44:590-594

Kahraman H, Erenler SO (2012) Rhamnolipid production by Pseudomonas aeruginosa engineered with the Vitreoscilla hemoglobin gene. Prikl Biokhim Mikrobiol 48:212-217

Kung SH, Retchless AC, Kwan JY, Almeida RPP (2013) Effects of DNA size on transformation and recombination efficiencies in Xylella fastidiosa. Appl Environ Microb 79:1712-1717. doi:10.1128/ Aem.03525-12

Liao B, Wang YX, Su JM, Liu F, He J (2014) Expression of Vitreoscilla hemoglobin in Bacillus thuringiensis BMB171 can promote manganese(II) oxidation under oxygen-restricted conditions. Ann Microbiol 64:1865-1868. doi:10.1007/s13213-014-0825-Z

Martos MA, Zubreski ER, Combina M, Garro OA, Hours RA (2013) Isolation of a yeast strain able to produce a polygalacturonase with maceration activity of cassava roots. Food Sci Technol 33:332-338

Mata-Gomez MA, Heerd D, Oyanguren-Garcia I, Barbero F, RitoPalomares M, Fernandez-Lahore M (2014) A novel pectindegrading enzyme complex from Aspergillus sojae ATCC 20235 mutants. J Sci Food Agric. doi:10.1002/jsfa.6864

Miller GL (1959) Use of dinitrosalicylic acid reagent for determination of reducing sugar. Anal Chem 31:426-428. doi:10.1021/Ac60147a030

Mora-Lugo R, Zimmermann J, Rizk AM, Fernandez-Lahore M (2014) Development of a transformation system for Aspergillus sojae based on the Agrobacterium tumefaciens -mediated approach. BMC Microbiol 14:247. doi:10.1186/s12866-014-0247-x

Oostra J, le Comte EP, van den Heuvel JC, Tramper J, Rinzema A (2001) Intra-particle oxygen diffusion limitation in solid-state fermentation. Biotechnol Bioeng 75:13-24. doi:10.1002/Bit.1159 
Ortiz GE, Guitart ME, Albertó E, Fernández-Lahore HM, Blasco M (2014) Microplate assay for endo-polygalacturonase activity determination based on ruthenium red method. Anal Biochem 454:33-35

Rahardjo YSP, Weber FJ, Haemers S, Tramper J, Rinzema A (2005) Aerial mycelia of Aspergillus oryzae accelerate alpha-amylase production in a model solid-state fermentation system. Enzyme Microb Tech 36:900-902. doi:10.1016/j.enzmictec.2005.01.010

Roos V, Andersson CIJ, Bulow L (2004) Gene expression profiling of Escherichia coli expressing double Vitreoscilla haemoglobin. J Biotechnol 114:107-120. doi:10.1016/j.jbiotec.2004.07.002

Shen J, Zheng H, Zhi X, Shi Y, Huang Y, Wang W, Chen Y, Kong J, Zhu $P$ (2012) Improvement of amorpha-4,11-diene production by a yeast-conform variant of Vitreoscilla hemoglobin. Z Naturforsch C 67:195-207

Silva D, Tokuioshi K, Martins ED, Da Silva R, Gomes E (2005) Production of pectinase by solid-state fermentation with Penicillium viridicatum RFC3. Process Biochem 40:2885-2889. doi:10.1016/j.procbio.2005.01.008

Stark BC, Pagilla KR, Dikshit KL (2015) Recent applications of Vitreoscilla hemoglobin technology in bioproduct synthesis and bioremediation. Appl Microbiol Biot 99:1627-1636. doi:10.1007/ s00253-014-6350-y

Stark BC, Dikshit KL, Pagilla KR (2011) Recent advances in understanding the structure, function, and biotechnological usefulness of the hemoglobin from the bacterium Vitreoscilla. Biotechnol Lett 33: 1705-1714. doi:10.1007/s10529-011-0621-9

Tari C, Dogan N, Gogus N (2008) Biochemical and thermal characterization of crude exo-polygalacturonase produced by Aspergillus sojae. Food Chem 111:824-829. doi:10.1016/j.foodchem.2008.04. 056

Tari C, Gogus N, Tokatli F (2007) Optimization of biomass, pellet size and polygalacturonase production by Aspergillus sojae ATCC 20235 using response surface methodology Enzyme. Microb Tech 40:1108-1116. doi:10.1016/j.enzmictec.2006.08.016

te Biesebeke R, Boussier A, van Biezen N, Braaksma M, van den Hondel CA, de Vos WM, Punt PJ (2006) Expression of Aspergillus hemoglobin domain activities in Aspergillus oryzae grown on solid substrates improves growth rate and enzyme production. Biotechnol J 1: 822-827. doi:10.1002/biot.200600036
Ustok FI, Tari C, Gogus N (2007) Solid-state production of polygalacturonase by Aspergillus sojae ATCC 20235. J Biotechnol 127:322-334. doi:10.1016/j.jbiotec.2006.07.010

Viniegra-Gonzalez G, Favela-Torres E, Aguilar CN, Romero-Gomez SD, Diaz-Godinez G, Augur C (2003) Advantages of fungal enzyme production in solid state over liquid fermentation systems. Biochem Eng J 13:157-167. doi:10.1016/S1369-703x(02)00128-6

Wakabayashi S, Matsubara H, Webster DA (1986) Primary sequence of a dimeric bacterial hemoglobin from Vitreoscilla. Nature 322:481483. doi: $10.1038 / 322481 \mathrm{a} 0$

Wang D, He D, Li G, Gao S, Lv H, Shan Q, Wang L (2014) An efficient tool for random insertional mutagenesis: Agrobacterium tumefaciens-mediated transformation of the filamentous fungus Aspergillus terreus. J Microbiol Methods 22:114-118

Ward OP (2012) Production of recombinant proteins by filamentous fungi. Biotechnol Adv 30:1119-1139. doi:10.1016/j.biotechadv.2011. 09.012

Webster DA (1987) Structure and function of bacterial hemoglobin and related proteins. Adv Inorg Biochem 7:245-265

Wei XX, Chen GQ (2008) Applications of the VHb gene vgb for improved microbial fermentation processes. Method Enzymol 436: 273. doi:10.1016/S0076-6879(08)36015-7

Wu JM, Fu WC (2012) Intracellular co-expression of Vitreoscilla hemoglobin enhances cell performance and beta-galactosidase production in Pichia pastoris. J Biosci Bioeng 113:332-337. doi:10.1016/j. jbiosc.2011.10.014

Zamani A, Jeihanipour A, Edebo L, Niklasson C, Taherzadeh MJ (2008) Determination of glucosamine and $\mathrm{N}$-acetyl glucosamine in fungal cell walls. J Agric Food Chem 56:8314-8318. doi:10.1021/ jf801478j

Zhang SM, Wang JP, Wei YL, Tang Q, Kanwal M, He J (2014) Heterologous expression of $\mathrm{VHb}$ can improve the yield and quality of biocontrol fungus Paecilomyces lilacinus, during submerged fermentation. J Biotechnol 187:147-153. doi:10.1016/j.jbiotec.2014. 07.438

Zhu H, Sun SJ, Zhang SASA (2011) Enhanced production of total flavones and exopolysaccharides via Vitreoscilla hemoglobin biosynthesis in Phellinus igniarius. Bioresource Technol 102:1747-1751. doi:10.1016/j.biortech.2010.08.085 